\title{
INFEKCIJA KIRURŠKE POSTOPERATIVNE RANE
}

\author{
Mateja Briševac bacc. med. teh. \\ Klinika za ženske bolesti i porode \\ KBC Zagreb \\ Rad je primljen 13.4.2016. \\ Rad je korigiran 17.3.2016. \\ Rad je prihvaćen 27.3.2016.
}

\section{SAŽETAK}

Infekcija postoperativne rane danas je jedan od vodećih uzroka mortaliteta u razvijenim zemljama Europe. Provođenje mjera koje imaju za cilj smanjenje izlaganja čimbenicima rizika, osiguravanjem adekvatnih operacijskih uvjeta, te mjera prevencije postoperacijske infekcije rane možemo doprinijeti smanjenju broja infekcija, a samim tim i padu morbiditeta. Prikazom dvije operirane bolesnice pokazali smo da infekcija postoperativne rane pridonosi morbiditetu i mortalitetu. Prva bolesnica je operirana u dobrim operacijskim uvjetima uz mali broj čimbenika rizika, te mjere postoperativne prevencije infekcije rane. Nije došlo do postoperativne infekcije rane. Otpuštena je izliječena s per primam zacijeljenom operacijskom ranom. Kod druge bolesnice na cijeljenje rane utječe onkološka bolest, pretilost, pušenje, dijabetes melitus, visoka starost, koža kontaminirana sa Staphilococus aureus, preoperacijsko ležanje, anemija, hipoksemija, uporaba imunosupresiva, iradijacija i nozokomijalna infekcija. Pseudomonas aeruginosa detektiran je kao uzročnik nozokomijalne infekcije postoperativne rane. Od operacijskih uvjeta koji pogoduju infekciji rane su duga operacija, jaka ozljeda tkiva, reintervencija i drenaža. Na čimbenike rizika od strane pacijenta nismo mogli utjecati, te samim tim nismo doveli do cijeljenja postoperacijske rane koja je pridonijela letalnom završetku pacijentice.

Ključne riječi: ginekologija, infekcija rane, infekcije, nadzor.

Osoba za razmjenu informacija:

Mateja Briševac bacc. med. teh.

e-mail: mateja.brisevac04@gmail.com

\section{UVOD}

Postoperativne infekcije rane usprkos antiseptičkim tehnikama predstavljaju veliki klinički problem (1). U Njemačkoj se godišnje napravi preko 5 milijuna operacija. Studija provedena od 1997. do 2004. godine u 164 bolnice u Njemačkoj, govori da se na 36,000 operiranih bolesnika kod njih 6,800 javila postoperacijska infekcija rane. Postoperacijske infekcije rane povezane su s porastom morbiditeta i letaliteta, produženim boravkom u bolnici, te s povećanom terapijom i cijenom liječenja $(1,3,4)$. Postoperacijske infekcije rane (Surgical Site Infection, SSI), u aktualnim istraživanjima stoje na prvom mjestu u bolnicama među nozokomijalnim infekcijama pored pneumonije, sepse i infekcija urinarnih putova (1). Postoperacijske infekcije rane doprinose povećanom mortalitetu i morbiditetu, te povećanom boravku u bolnicama za 7-8 dana. Postoperativne infekcije rane asocirane su uglavnom sa: Staphilococus aureus, Pseudomonas aeruginosa, Serratia marcescens, Klebsiella pneumoniae, Enterococcus foecalis i Candida spp (1-4). Po podacima
KISS (bolnički sustav za nadzor nad infekcijama (KISS - Krankenhaus - Infektions-Surveillance system) na 100 pacijenata nastanu dvije postoperativne infekcije rane (1). Broj nozokomijalnih infekcija u Njemačkoj se procjenjuje od 400000 - 600000 godišnje. Postoperacijska učestalost infekcija rane je oko $1,8 \%$. Na 100 postoperativnih rana na njih 2 nastupi infekcija. Infekcije postoperacijskih rana u Njemačkoj uzimaju dodatnih milijun bolničkih dana po godini. Udio MRSA različit je kod različitih operacijskih područja (1-5).

\section{Faktori rizika}

Rizik nastanka postoperacijske infekcije rane ovisi o mnogo čimbenika: od osobnih sklonosti pacijenata, do čimbenika rizika na koje možemo utjecati organizacijom preoperativne skrbi (1- 5).

Ovisno o području operacije, ulogu igraju enterobakterije i enterokoki. Gram negativni anaerobi npr. Bacteroides spp. imaju u ukupnom broju infekcija neznatnu ulogu $(3,5)$. 
Tablica 1: Čimbenici rizika

\begin{tabular}{|c|c|c|c|}
\hline Vezani uz pacijenta & Specifični za operaciju & Preoperativni & Postoperativni \\
\hline $\begin{array}{l}\text { - } \text { prijašnje/prateće bolesti } \\
\text { - } \text { postojanjje infekcija na drugim dijelovima } \\
\text { - } \text { tijela } \\
\text { - nazalna kolonizacija sa S.aureusom } \\
\text { - malnutricija } \\
\text { - adipositas } \\
\text { - } \text { pušenje } \\
\text { - maligna bolest, stadij tumora } \\
\text { - terapija citostaticima } \\
\text { - } \text { anemija (preoperativno i postoperativno) }\end{array}$ & $\begin{array}{l}\text { - dugi zahvat, operacijska tehnika } \\
\text { uključujućí krvarenje } \\
\text { - vrsta zahvata hitni, elektivni, } \\
\text { stupanj kontaminacije } \\
\text { - implantati, strana tijela }\end{array}$ & $\begin{array}{l}\text { - } \text { dugi boravak u bolnici } \\
\text { - neprikladno preoperativno uklonjene } \\
\text { dlake } \\
\text { - } \text { neprikladno očišćena koža/dezinfekcija } \\
\text { kože (preoperativni antiseptik) } \\
\text { - } \text { neprikladna preoperativna profilaksa } \\
\text { antibioticima } \\
\text { - } \text { otklon od fiziološke tjelesne temperature } \\
\quad \text { pacijenta } \\
\text { - } \text { hipoksija ili oksigenacija }\end{array}$ & $\begin{array}{l}\text { - } \text { drenaža, vrsta i trajanje } \\
\text { - } \text { postoperacijske invazivne mjere } \\
\text { povezane sa bakterijemijom } \\
\text { - } \text { nepotpuna postoperaciijska opskrba } \\
\text { rane } \\
\text { - vrsta postoperacijske prehrane }\end{array}$ \\
\hline
\end{tabular}

Organizam na ozljedu odgovara odmah poslije prekida integriteta cijeljenjem da bi ozlijeđeno tkivo nadomjestio vitalnim odnosno da bi se napravila reparacija ili restitucija $(8,10)$.

Opći planovi zdravstvene njege su izrađeni na način da svaka medicinska sestra prvostupnica može odabrati dijagnozu kao područje djelovanja u sklopu zdravstvene njege. Uz svaku dijagnozu su pribrojeni najčešći mogući kritični čimbenici, moguća vodeća obilježja, najčešći ciljevi, intervencije i neke moguće evaluacije.

Sestrinske dijagnoze uključuju: visok rizik od infekcije, visok rizik za dekubitus, smanjeno podnošenje napora, smanjena mogućnost brige o sebi (eliminacija, kupanje, hranjenje, odijevanje i dotjerivanje). Posebnu pažnju posvećujemo dijagnozi visokog rizika od infekcija.

\section{Prikaz slučaja}

Ispitanici su dvije bolesnice, stare 34. i 64. godine koje su operirane u Kliničkom bolničkom centru Zagreb (KBC) na Klinici za ženske bolesti i porode. Prva bolesnica operirana je zbog dobroćudne novotvorine maternice (myoma uteri) i postoperativni tijek prolazi bez komplikacija. Druga bolesnica operirana je radi zloćudne novotvorine maternice s presadnicama (adenocarcinoma uteri) i u postoperativnom tijeku dolazi do razvoja infekcije operacijske rane.

Pacijentice su liječene na Klinici u periodu: prva bolesnica od 23. 4. - 2. 5. 2014. godine; druga bolesnica od 27. 12. 2013. - 3. 10. 2015. godine. Korišteni podaci uzeti su retrospektivno, na temelju dostupne medicinske dokumentacije, iz središnje bolničke elektroničke baze podataka.

\section{Prva bolesnica}

Prva prikazana bolesnica u dobi od 34 godine, tjelesne težine $68 \mathrm{~kg}$, tjelesne visine $168 \mathrm{~cm}$, BMI 24.1, ASA I, te bez pratećih komorbiditeta.

Anamneza:

Osobna: Javlja se zbog bolova u donjem trbuhu s vaginalnim krvarenjem koje se ponavlja, te dugih, obilnih i iscrpljujućih menstruacija. Osjeća slabost i iznemoglost, te napetost i težinu u donjem abdomenu.

Obiteljska: Bez osobitosti.

Opis problema zbog kojeg bolesnica dolazi: Duge i obilne menstruacije, bolovi u maloj zdjelici, slabost. Dijagnoza: Myoma uteri.

Tijek i ishod bolesti: Napravljen operacijski zahvat donja medijalna laparotomija, izvađena maternica. Tijekom postoperacijskog boravka dolazi do brzog cijeljenja rane per primam bez lokalne inflamacije, te se 5-og dana skidaju kopčice uz uredan lokalni nalaz. Pacijentica se otpušta kući kao izliječena 11. dan po prijemu.

\section{Druga bolesnica}

Druga prikazana bolesnica je u dobi od 64 godine, tjelesne težine $130 \mathrm{~kg}, 165 \mathrm{~cm}$ tjelesne visine, RR 150/80, indeks tjelesne mase (BMI) 47,8, pretila BMI III, klasifikacija fizikalnog sistema (ASA) III.

\section{Anamneza:}

Osobna: liječi se već duže vrijeme od poremećaja srčane akcije, visokog krvnog tlaka, afunkcije lijevog bubrega, dijabetes melitusa tip II i pretilosti.

Obiteljska: nisu zabilježena maligna oboljenja.

Opis problema zbog kojeg bolesnica dolazi: duže vrijeme osjeća napetost i povremeno bolove u trbuhu, te povremeno zatvor. Trbuh joj je dobio na 
obujmu, a dijagnostičkom obradom je nađena sumnjiva tumorska tvorba u području uterusa, lijeve polovice zdjelice i retroperitoneuma lijevog $\mathrm{m}$. psoasa. Operativno izvađena maternica, patohistološki je utvrđeno da se radi o adenokarcinomu endometrija $s$ metastatskim promjenama u regionalnim limfnim čvorovima i udaljenim organima. Postavljenje su joj sljedeće dijagnoze: zloćudna novotvorina maternice s metastazama (adenocarcinoma uteri cum meta), poremećaj srčane akcije, visok krvni tlak, afunkcija lijevog bubrega, diabetes melitus i debljina, kamen u žučnom mjehuru, anemija, insufitientio renalis, trombocitopenija.

Tijekom boravka dolazi do dehiscijencije i infekcije operacijske rane, te se u dva navrata učini u općoj anesteziji debridman i resutura. Svakodnevno s provodila toaleta rane, uzimali brisevi, uradila se prilagodba antibiotske terapije prema antibiogramu, parametri upale su laboratorijski i klinički praćeni.

U daljem tijeku liječenja bolesnica je hospitalizirana u više navrata zbog dehiscijencije rane, provođenja kemoterapije i radioterapije. Postoperativno inficirana rana: rubovi rane crveni, razmaknuti u dužini od $17 \mathrm{~cm}$, nekrotično tkivo žućkasto-zelenkasto na rubovima, uz prisutnost devitaliziranog tkiva neugodnog mirisa, nekrotične fibrinske naslage na dnu rane sa sekrecijom žućkasto-zelenkastog sadržaja.

Iz brisa rane izolirani su Pseudomonas aeuriginosa, Escherichia coli ESBL, Staphylococcus aureus MRSA. Bolesnica je egzitirala u terminalnoj fazi maligne bolesti 15.1.2015.

Slika 1 i slika 2 prikazuju inficiranu postoperativnu ranu druge bolesnice

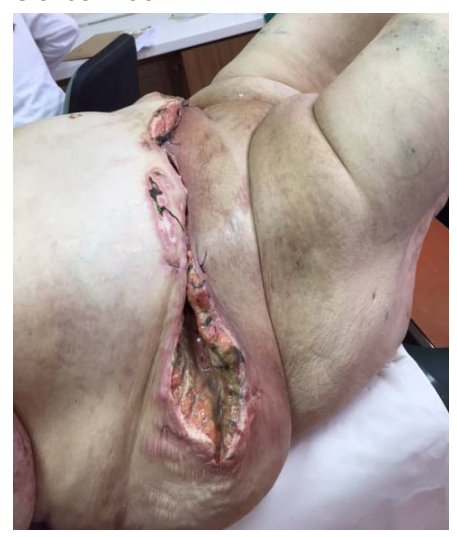

Slika 1: Inficirana postoperativna rana

\section{RASPRAVA}

Morbiditet i mortalitet zbog infekcija postoperativne rane je na trećem mjestu iza upala pluća i uroinfekcija. U većini slučajeva postoperacijska infekcija rane u operacijskom području nastaje između 3.-8. postoperacijskog dana poslije primarnog zatvaranja rane (1-3). Hakenberg i surr. izvještavaju da je kod ginekoloških operacija vodeći uzročnik infekcije postoperativne rane Pseudomonas aeruginosa. Također tvrde da treba smanjiti što je više moguće faktore rizika za nastanak postoperativne infekcije rane. To smanjenje može dovesti do smanjenja pojavnosti infekcija postoperativne rane za oko $34 \%$ (1). Prije velikog operativnog zahvata nužno je u preoperacijskom razgovoru pacijentice upoznati $s$ rizikom mogućeg nastanka infekcije kirurške rane $(1,3)$. S pacijenticama je obavljen preoperacijski razgovor i upozorene su na mogućnost nastanka postoperacijske infekcije rane, predočeni su im rizici koji povećavaju mogućnost nastanka infekcije rane.

Hachenberg (1) izvještava da se spektar uzročnika infekcije postoperativne rane nije bitno mijenjao posljednjih godina. Navodi da je i dalje po KISS-u (Krankenhaus-Infections-Surveillance-System-Sustav za kontrolu infekcija u bolnicama) najčešći uzročnik postoperacijskih rana u ginekologiji Stafilococcus aureus s učestalošću od 24,2 \%, dok je Pseudomonas aeruginosa uzrokovao 2,5 \% infekcija operacijske rane kod ginekoloških bolesnica. Broj bakterija i virulencija su značajne odrednice infekcije rane. Čimbenici domaćina su od velike važnosti. Bakterije porijeklom iz bolničke sredine su u pravilu

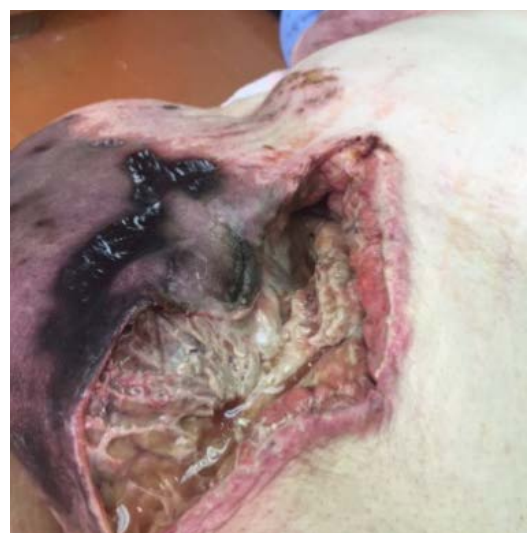

Slika 2: Inficirana postoperativna rana 
mnogo otpornije na antibiotike, pa se i infekcije koje one izazivaju mnogo teže liječe $(10,22)$.

Hakenberg sa suradnicima $(1,22)$ pokazuje da čimbenici rizika za postoperativnu infekciju rane, izraženi u bodovima različito doprinose nastanku infekcije rane. Najistaknutiji su mikrobiološko stanje rane $(6,4)$, hitnost zahvata $(2,0)$, trajanje operacije ( 1,5 bodova po satu), antimikrobna profilaksa $(5,3)$, boravak u bolnici $(1,1)$, malignom $(1,7)$, starost $(1,2)$.

Druga bolesnica ima zbrojno jako visoki skor za postoperativnu infekciju rane (Tablica 2). Jasno je da se kod druge bolesnice starije dobi radilo o malignoj bolesti, te teškoj, velikoj i dugoj operaciji (imajući u obziru dug boravak u bolnici, te da je reoperirana više puta). Uz to postoji debljina, dijabetes melitus, a radi se i o kardiovaskularnom bolesniku. Postojala je većina čimbenika rizika koji su doprinijeli razvoju infekcije postoperativne rane (tablica 1.2). U konačnici je to i rezultiralo razvojem infekcije rane, koja je doprinijela samom ishodu bolesti. Zasićenost rane Pseudomonasom aeruginosa nadmašuje sile cijeljenja rana i javlja se poremećaj u cijeljenju rane $(10,22)$.

Mjere prevencije postoperativne infekcije u operacijskom području $(4,22)$ kod prikazanih bolesnica jednako su provedene, $s$ tim da se kod prve bolesnice nije razvila infekcija postoperacije rane, zbog izostanka faktora rizika za infekciju postoperativne rane, a kod druge bolesnice došlo je do razvoja infekcije postoperativne rane jer su postojali skoro svi faktori rizika vezani za pacijenta (tablica 1.2)

Postoperacijski čimbenici rizika $(1,5,22)$, kao što su drenaža, postoperacijske invazivne mjere povezane $s$ bakterijemijom, pridonijele su nastanku infekcije rane kod druge bolesnice. Kod druge prikazane bolesnice bili su prisutni gotovo svi čimbenici rizika vezani uz pacijenta te se i javila postoperativna infekcija rane.

ASA skor govori o izraženom riziku za anesteziju za vrijeme operacijskog zahvata. ASA III govori da se radi o teškom bolesniku s izraženim rizikom komplikacija za vrijeme anestezije što korelira povećanim stopama infekcije postoperativne rane.
Hachenberg sa suradnicima (1) također tvrdi da kirurške tehnike, te vođenje anestezije i poremećaji hemostaze, oksigenacije, kontrole tjelesne temperature i trajanje operacijskog zahvata mogu utjecati na rizik od infekcije (1). U obje prikazane bolesnice monitorirane su osnovne funkcije i provedena je briga poravnanja fizioloških hemostaza, te to nije moglo utjecati na pojavu postoperativne infekcije rane. Kod druge bolesnice dugotrajnost operacijskog zahvata i ponavljani zahvati utjecali su na pojavu postoperativne infekcije rane.

Sve postoperacijske mjere i postupci navedeni $\mathrm{u}$ preporukama $(5,22)$ provedeni su od strane osoblja, $s$ instrumentima, operacijskom sredinom i premještajem u jedinicu intenzivnog liječenja kod obje bolesnice jednako, te nisu mogle utjecati na pojavu postoperacijske infekcije rane.

Seiler sa suradnicima u studiji na 200 pacijenata (15) dokazao je da intenzitet i trajanje boli kao i cijeljenje rane ne ovisi o tome kako se otvara trbušna šupljina poprečnim ili uzdužnim medijalnim rezom. Preporuča da se rez bira od strane kirurga individualno

Vrsta reza kod bolesnica nije mogla utjecati na cijeljenje rane.

Seiler sa suradnicima izvještava (15) da na infekciju rane utječe iskustvo, disciplina i tehnika kirurga koji operira. Vjerojatnost infekcije je veća što kirurg ima manje operacija, a smanjuje se kod kirurga koji ima više operacijskih zahvata. Naše bolesnice operirao je isti kirurg, uvježban, velike discipline i iskustva, s puno operacija, te to nema utjecaja na infekciju postoperacijske rane. 
Tablica 2: CDC smjernice 1999. za prevenciju postoperacijskih infekcije rane $(1,17)$

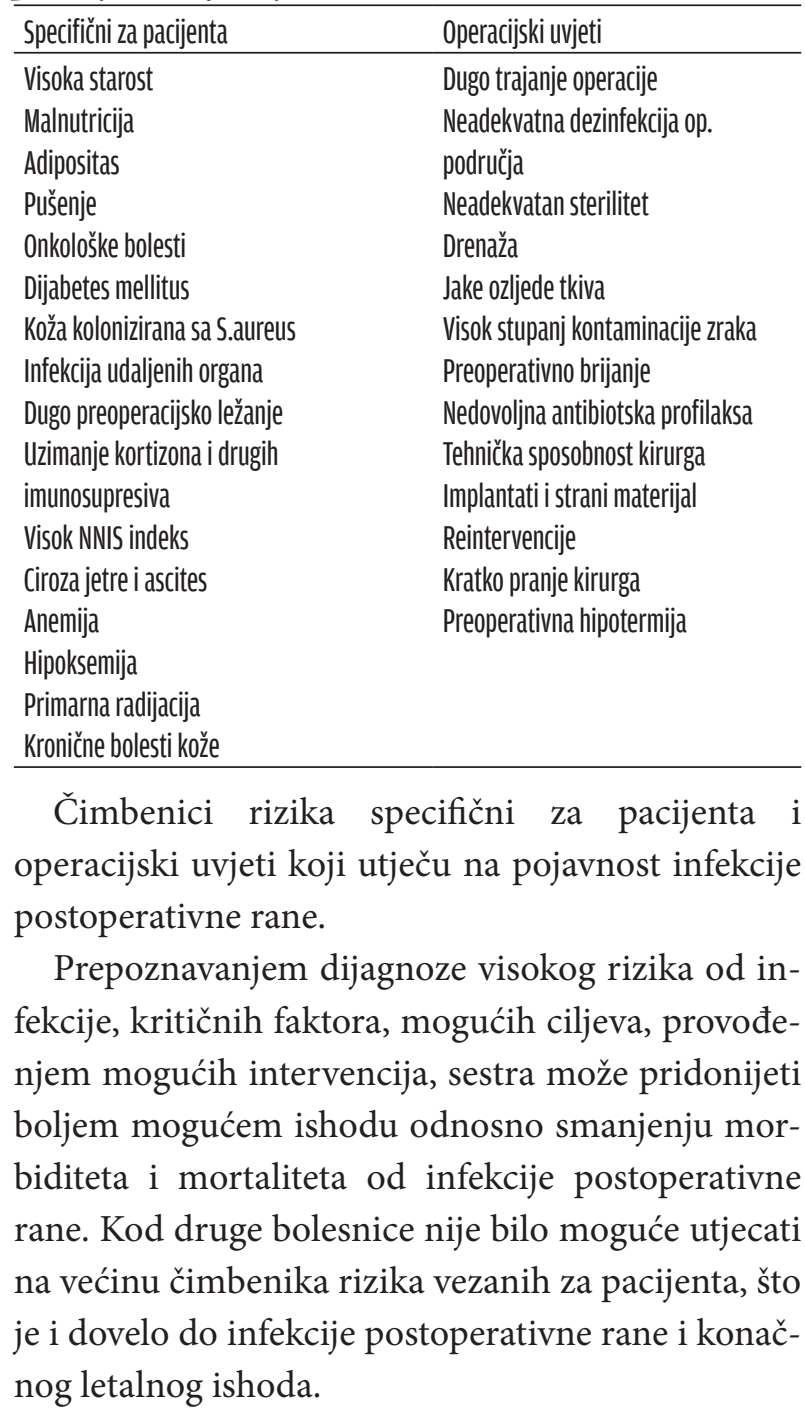

\section{ZAKLJUČAK}

Infekcija postoperativne kirurške rane posljedica je postojanja uvjeta specifičnih za pacijenta: visoka starost, pretilost, pušenje, onkološke bolesti, dijabetes melitus, koža kontaminirana Staphilococcus aureus-om, dugo preoperacijsko ležanje, uporaba imunosupresiva, anemije, hipoksemije te iradijacije. Operacijski uvjeti koji su pospješili razvoj postoperativne infekcije rane su: duga operacija s velikom ozljedom tkiva, reintervencija i drenaža. Pseudomonas aeuriginosa predstavlja uzročnika nozokomijalne infekcije. Prevencije čimbenika rizika i mjere prevencije postoperacijske infekcije nisu utjecale na razvoj postoperativne infekcije rane. Sestra pridonosi evaluaciji mogućeg ishoda prepoznavanjem dijagnoze visokog rizika od infekcije, prepoznavanjem kritičnih čimbenika i nužnih intervencija u cilju ostvarenja postavljenih ciljeva. Prevencija razvoja čimbenika rizika utječe na smanjenje mortaliteta i morbiditeta zbog postoperativne infekcije rane.

\section{LITERATURA}

1. Hakenberg T, Sentürk M, Jannasch O, Lippert H. Postoperative Wundinfektionen. Anaesthesist. 2010; 59:851-868.

2. Arbeitskreis „Krankenhaus- und Praxishygiene“ der AWMF. Strategien zur Prävention von postoperativen Wundinfektionen. Hyg Med. 2014;39-4.

3. Gastmeier P, Brandt C, Sohr D, Babikir R, Mlageni D, Daschner F, Rüden H. Postoperative WundInfektionen nach stationären und ambulanten Operationen. Bundesgesundheitsbl-Gesundheitsforsch-Gesundheitschutz. 2004;47:339-344.

4. Kappstein I, Schulgen G, Richtmann R et al. Verlängerung der Krankenhausverweildauer durch nasocomiale- Pneumonie und Wundinfektion. Dzsch Med Wochenschr. 1991;116:281-287.

4. Deutsche Gesellschaft für Krankenhaushygiene (DGKH). Prävention postoperativer Infektionen im Operationsgebiet: Empfelung der Kommission für Krankenhaushygiene und Infektionsprävention beim Robert Koch Institut. GMS Krankenhaushyg Interdiszip. 2007;2:57.

5. Huljev D, Gajić A. Debridement. Acta Med Croatica. 2011;66:63-8.

6. Huljev D, Gajić A, Triller C, Kecelj Leskovec T. Uloga debridementa liječenju kroničnih rana. Acta Med Croatica. 2012;66:79-84.

7. Huljev D. Prepreke u cijeljenju rane. Acta Med Croatica. 2013;67:5-10.

8. Saftdar N, Bradley EA. The risk of infection after nasal colonisation with Staphylococcus aureus. Am J Med.2008;121:310-5.

9. Mogford JE, Mustoe TA. Experimental models of wound healing. U: Falanga V, ed. Cutaneus Wound Healing. London: Martin Dunitz Ltd. 2001.

10. Vraneš J, Drenjančević D. Antibiotička terapija kroničnih rana. Medix 2003:51:45-47. 
11. Reutter F, Reuter DA, Hilgarth H, Heilek AM, Goepfert MS, Punke MA. Perioperative Antibiotikaprophylaxe. Anaesthesist. 2014;63:73-86.

12. Banić M, Kardum D, Petričušić L, Urek-Crnčević M, Pleško S, Kujundžić M. Dijabetičko stopala: značenje prehrane bolesnika. Acta Med Croatica 2010; 64:109.

13. Medina A, Scott PG, Ghahary A, Tredget EE. Pathophysiology of chronic nonhealing wounds. J Burn Care Rehabil. 2005;26:306-19.

14. Rogulj Mandrac I, Peraica Planinc A, Ostojić Kolonić S. Rane kod hematoloških bolesnika . Acta Med. Croatica. 2012;66;99-101.

15. Seiler, CM, Deckert, Diener MK, Knaebel HP, Weigand MA, Victor N, Büchler MW. Midline versus transverse incison in major abdopminal surgery, a randomized, doubleblind equivalence trial. Annals of surgery. 2009;249:913-920.
16. Mangram AJ, Horan TC, Pearson ML, Silver LC, Jarvis WR. Guideline for prevention of surgical site infection, 1999. Hospital Infection Control Practices Advisory Committee. Infect Control Hosp Epidemiol. 1999;20(4):250-78; quiz 27980.

17.Hkms.hr [Internet]. Sestrinske dijagnoze. Dostupno na: www.hkms.hr.

19. Wikipedia. com [Internet]. Rana. Dostupno na: https://bs.wikipedia.org/wiki/)

20. Wikipedia.org [Internet]. Wundheilung. Dostupno na:https://de.wikipedia.org/wiki/)

21. Medizinfo.de [Internet]. Wundmenagement Dostupno na: www.medizinfo.de/wundmwnagement/formen.htm)

22. Bundesgesundheitsbl.gesundheitsforsch-gesundheitschutz. Prevention postoperativer Infektionen im Operations gebiet. 2007;50:377-393 


\title{
INFECTION OF SURGICAL POSTOPERATIVE WOUND
}

\author{
Mateja Briševac bacc. med. tech. \\ Clinic for Obstetrics and Gynecology \\ Clinical Hospital Center Zagreb
}

\begin{abstract}
Infection of postoperative wound is one of the leading causes of mortality in developed countries of Europe. Implementation of measures aimed at reducing exposure to risk factors, ensuring adequate operating conditions, and measures of prevention of postoperative wound infections can contribute to the reduce of the number of infections, and therefore the decline in morbidity.

Depicting two operated patients we have shown that postoperative infection of wound contributes to morbidity and mortality. The first patient was operated in good operating conditions with a small number of risk factors, and measures of prevention of post-operative wound infection. There was no post-operative wound infection. She was discharged cured with per primam healed wound. The wound healing in other patient is affected by oncological disease, obesity, smoking, diabetes, advanced age, the skin contaminated with Staphylococcus aureus, preoperative lying, anemia, hypoxemia, use of immunosuppressants, irradiation and nosocomial infections. Pseudomonas aeruginosa was detected as the cause of nosocomial infection of post-operative wounds. Operating conditions which serve the infection of wound are long surgery, strong tissue injury, reintervention and drainage. The risk factors of the patient could not be affected, and therefore it did not lead to the healing of postoperative wound, which contributed to a lethal end of the patient.
\end{abstract}

Keywords: gynecology, wound infection, infections, control.

Correspondence:

Mateja Briševac bacc. med. teh.

e-mail: mateja.brisevac04@gmail.com 